\title{
Pembiayaan Sindikasi Bank Syariah di Indonesia dalam Perspektif Hukum Ekonomi Syariah
}

\author{
Dery Ariswanto $^{1}$, Zedra Warang ${ }^{2}$, dan Agung Wildan Azizi ${ }^{3}$ \\ ${ }^{1}$ Program Studi Magister Hukum Ekonomi Syariah Pascasarjana Universitas Islam Negeri (UIN) Sunan Gunung \\ Djati Bandung, email: dery0712@gmail.com \\ ${ }^{2}$ Pascasarjana Universitas Islam Negeri (UIN) Sunan Gunung Djati Bandung \\ ${ }^{3}$ Pascasarjana Universitas Islam Negeri (UIN) Sunan Gunung Djati Bandung
}

\begin{abstract}
This article aims to describe and analyze the syndicated financing of Islamic Banks in Indonesia from the perspective of Islamic Economics Law. This study uses a qualitative research method with the type of library research used to analyze the formulation of the problem in this study. The results of this study indicate that the product innovation of Islamic banking can be carried out by applying a contract that is hybrid contract or multi-contract in nature. Sharia syndicated financing products emerge in the banking on the basis of the need for large amounts of financing, so that Islamic Banks will not be able to support it alone in other words, they must cooperate with other banks. Syndication financing is allowed based on the Fatwa DSN No: 91/DSN-MUI/IV/2014. Syndicated financing in Islamic Banks generally uses the musyarakah mutanaqishah contract. Syndicated financing in Islamic Banks has accommodated the provisions of both the Sharia Banking Law, KHES, Fatwa $D S N$, and other related regulations. So that the implementation of syndicated financing products at Islamic Banks in Indonesia is in principle aligned with Sharia Economic Law, however it must continue to be supervised by the Sharia Supervisory Board so that there are no violations of existing regulations.
\end{abstract}

Keywords: Islamic bank, financing, syndication

\begin{abstract}
Abstrak
Artikel ini bertujuan untuk mendeskripsikan dan menganalisis tentang pembiayaan sindikasi Bank Syariah di Indonesia dari perspektif Hukum Ekonomi Syariah. Penelitian ini menggunakan metode penelitian kualitatif dengan jenis penelitian kepustakaan (library research), yang digunakan untuk menganalisis rumusan masalah dalam penelitian ini. Hasil penelitian ini menunjukkan bahwa inovasi produk perbankan syariah dapat dilakukan dengan menerapkan akad yang bersifat hybrid contract atau multi contract. Produk pembiayaan sindikasi muncul di dunia perbankan atas dasar kebutuhan pembiayaan dalam jumlah besar, sehingga bank syariah tidak akan dapat mendukungnya sendiri dengan kata lain harus bekerjasama dengan bank lain. Pembiayaan sindikasi diperbolehkan berdasarkan Fatwa DSN nomor 91/DSN-MUI/IV/2014. Pembiayaan sindikasi syariah di bank syariah pada umumnya menggunakan akad musyarakah mutanaqishah. Pembiayaan sindikasi pada Bank Syariah telah mengakomodir ketentuan baik UU Perbankan Syariah, KHES, Fatwa DSN, dan ketentuan terkait lainnya. Sehingga penerapan produk pembiayaan sindikasi pada Bank Syariah di Indonesia pada prinsipnya telah selaras dengan Hukum Ekonomi Syariah, namun masih harus terus mendapatkan pengawasan oleh Dewan Pengawas Syariah agar tidak terjadi pelanggaran terhadap ketentuan yang berlaku.
\end{abstract}

Kata Kunci: Bank Syariah, pembiayaan, sindikasi 


\section{Pendahuluan}

Bank Syariah mempunyai keharusan melakukan pengembangan inovasi produk untuk menjaga eksistensi perbankan syariah agar terus meningkat di tengah persaingan. ${ }^{1}$ Bank Syariah dalam kegiatan usahanya menggunakan beberapa produk yang meliputi penghimpunan dana, pembiayaan atau penyaluran dana dan jasa perbankan lainnya. ${ }^{2}$ Perbankan syariah dalam hal memberikan pembiayaan kepada nasabah dapat dikategorikan pada dua segmen, yakni segmen UMKM dan non UMKM. Pembiayaan pada segmen non UMKM akhir-akhir ini mengalami peningkatan yang cukup membanggakan. Selama empat tahun terakhir pertumbuhan pembiayaan terhadap sektor non UMKM tergolong berkembang. Dimulai tahun 2016, investasi pada sektor non UMKM yang dibiayai oleh Bank Syariah sebanyak 41,33 triliun. Terjadi peningkatan pada tahun berikutnya, tahun 2017 senilai 45,73 triliun dan tahun 2018 senilai 51,08 triliun. Sedangkan di tahun 2019 nilainya sudah lebih dari 61 triliun. Hal demikian seperti dilansir oleh data statistik perbankan syariah dari Otoritas Jasa Keuangan. ${ }^{3}$

Statistik tersebut membuktikan bahwa pembiayaan yang dilakukan oleh perbankan syariah tidak hanya terpaku pada pembiayaan sektor usaha mikro, kecil dan menengah. Namun pada segmentasi yang lebih besar juga tidak kalah menarik untuk dilirik para nasabah, meskipun secara kuantitas nilainya masih jauh dari di bawah pembiayaan sektor UMKM. Kapasitas pembiayaan yang dilakukan secara mandiri oleh sebuah Bank Syariah jumlahnya terhitung masih kecil apabila dibandingkan dengan kebutuhan terhadap pembiayaan industri yang begitu besar dewasa ini. Terbatasnya modal utama perbankan syariah menyebabkan industri perbankan syariah harus mencari jalan keluar untuk melakukan akses pembiayaan atau investasi dalam jumlah banyak.

Seiring perkembangan usaha dan meningkatnya kebutuhan pembiayaan investasi dengan jumlah yang besar, seringkali diperlukan lebih dari satu bank dan/atau lembaga keuangan syariah untuk secara bersama-sama memenuhi kebutuhan keuangan tersebut. Konsep itulah yang kemudian disebut dengan sindikasi. Syndicated loan atau dalam istilah bahasa Indonesia disebut sebagai kredit sindikasi/ pembiayaan sindikasi merupakan pembiayaan atau pinjaman yang diberikan secara bersama-sama oleh lebih dari satu bank kepada suatu debitur tertentu yang membutuhkan pembiayaan. Pembiayaan sindikasi dapat berupa kredit investasi atau juga kredit modal kerja.

Pembiayaan sindikasi muncul dalam perbankan atas dasar kebutuhan terhadap pembiayaan dengan jumlah besar, sehingga perbankan tidak mampu jika hanya dilakukan oleh satu bank saja. Di lain sisi, pembiayaan jumlah besar juga pasti diikuti dengan resiko yang besar pula. Pembiayaan sindikasi hadir sebagai salah satu cara untuk memperkecil

1 Ferlangga Al Yozika and Nurul Khalifah, "Pengembangan Inovasi Produk Keuangan Dan Perbankan Syariah Dalam Mempertahankan Dan Meningkatkan Kepuasan Nasabah," Jurnal Ilmiah Edunomika 1, no. 02 (August 21, 2017): hlm, 101, https://doi.org/10.29040/jie.v1i02.154.

2 Ascarya dan Diana Yumanita, Gambaran Umum Bank Syariah (Jakarta: PPSK BI, 2005), hlm. 5.

3 Ni Putu Eka Wiratmini, Sindikasi Syariah Berpotensi Naik, Financial Bisnis, https:// finansial.bisnis.com/read/20200209/90/1199080/sindikasi-syariah-berpotensi-naik, diakses pada tanggal 18 Oktober 2020 Pukul 13:00 WIB. 
resiko karena pembiayaan dilakukan oleh dua bank atau lebih sehingga akan mencerminkan prinsip berbagi resiko. Perbankan syariah di Indonesia telah banyak melakukan pembiayaan terhadap investasi jumlah besar yang sangat berpengaruh kepada perekonomian. Misalnya melalui produk Pembiayaan Sindikasi iB Hasanah di BNI Syariah, Kredit Sindikasi di Bank Syariah Mandiri, Sindikasi di BCA Syariah dan pembiayaan sindikasi perbankan syariah lainnya di Indonesia. Pembiayaan terhadap investasi ini tidak dapat dijalankan sendiri oleh satu Bank Syariah, melainkan harus bekerja sama dengan bank lainnya.

Pembiayaan sindikasi pada perbankan syariah memiliki komponen yang sangat banyak. Mulai dari hubungan yang terjalin antara sesama lembaga penyedia modal baik bank maupun non bank atau relasi antara lembaga keuangan konvensional dan lembaga keuangan berprinsip syariah. Di samping itu juga terdapat hubungan antara pihak penyedia modal (lembaga keuangan) dengan pihak yang membutuhkan pembiayaan atau disebut nasabah. Sebagaimana sindikasi adalah pembiayaan yang dilakukan oleh lebih dari dua bank terhadap kebutuhan pembiayaan nasabah baik berupa pembiayaan infrastruktur, listrik, telekomunikasi, dan proyek usaha besar lainnya.

Kerjasama sindikasi pada perbankan syariah dapat dilakukan oleh sesama Bank Syariah atau antara Bank Syariah satu dengan bank konvensional untuk bersama-sama membiayai kebutuhan nasabah yang dalam hal ini memiliki perjanjian/ akad yang tidak hanya satu. Beberapa kontrak/ akad dalam pembiayaan sindikasi Bank Syariah dibuat untuk mengisi celah akibat adanya hubungan timbal balik antara beberapa pihak yang terkait dengan pembiayaan ini. Produk pembiayaan ini tidak dapat dipisahkan dengan skema multi akad (hybrid contract) dalam teori hukum ekonomi syariah atau fiqh muamalah.

Berdasarkan hal-hal yang telah diulas sebelumnya, maka dalam artikel ini akan dirumuskan beberapa permasalahan sebagai fokus penelitiannya yakni tentang bagaimanakah penerapan produk sindikasi di perbankan syariah, sejauhmana pembiayaan tersebut dapat menjadi solusi bagi proyeksi pembangunan perekonomian kedepan baik bagi nasabah juga perbankan syariah itu sendiri, bagaimana ketentuan dari pemberlakuan pembiayaan sindikasi di Bank Syariah beserta kaitannya dengan multi akad yang digunakan. Penelitian ini secara khusus akan menggambarkan dan menganalisis tentang tinjauan hukum ekonomi syariah terhadap pembiayaan sindikasi Bank Syariah di Indonesia.

\section{Metode Penelitian}

Penelitian ini menggunakan metode penelitian kualitatif dengan memakai jenis penelitian kepustakaan (library research) yakni berdasarkan sumber dan rujukan yang dihasilkan dari literatur-literatur pustaka seperti buku-buku, jurnal, penelitian, dan lainnya. Sifat dari penelitian ini adalah deskriptif-analisis, yakni penelitian ini dilakukan dengan tujuan untuk mendeskribsikan praktik dan konsep pembiayaan sindikasi pada bank syariah di Indonesia kemudian ditinjau dan dianalisis menggunakan sudut pandang hukum ekonomi syariah. Sedangkan teknik analisis data dalam penelitian ini menggunakan teknik analisis data induktif.

\section{Pembahasan}

\section{A. Gambaran Umum Pembiayaan Sindikasi Bank Syariah di Indonesia}




\section{1) Pengertian Pembiayaan Sindikasi}

Sindikasi menurut kamus yang dimuat dalam situs resmi Bank Indonesia yakni pemberian kredit oleh sekelompok bank kepada satu debitur yang jumlahnya terlalu besar jika diberikan oleh satu bank saja (loan syndication). Pada awalnya kredit sindikasi di Indonesia diatur dalam Surat Edaran Bank Indonesia No. 6/33/UPK tanggal 3 Oktober 1973 mengenai Pembiayaan Bersama oleh Bank-Bank Pemerintah dan Surat Edaran Bank Indonesia No. 11/26/UPK yang dikeluarkan pada tahun 1979. Ketentuan sindikasi termaktub dalam Surat Edaran Bank Indonesia No. 7/23/DPD tertanggal 8 Juli 2005 dan Peraturan Bank Indonesia No. 7/14/PBI/2005 tentang Pembatasan Transaksi Rupiah dan Pemberian Kredit Valuta Asing oleh Bank. Pembiayaan sindikasi atau pinjaman sindikasi menurut Stanley Hurn ialah pinjaman yang dibuat oleh dua atau lebih lembaga pemberi pinjaman, dengan syarat dan kode yang sama, menggunakan dokumentasi umum dan dikelola oleh agen umum. ${ }^{4}$ Secara definitif, pembiayaan sindikasi merupakan pembiayaan yang diberikan oleh lebih dari satu lembaga keuangan bank untuk satu objek pembiyaan tertentu. Umumnya, pembiayaan tersebut diberikan bank kepada nasabah korporasi yang memiliki nilai transaksi yang sangat besar. ${ }^{5}$

Dalam pengertian lain yang lebih spesifik tentang pembiayaan sindikasi syariah dapat dipahami seperti apa yang tertuang dalam fatwa Dewan Syariah Nasional MUI. Pembiayaan sindikasi (al-tamwil al-mashrifi al-mujamma') merupakan sebuah akad antara beberapa Lembaga Keuangan, baik antar sesama Lembaga Keuangan Syariah maupun antar Lembaga Keuangan Syariah dengan Lembaga Keuangan Konvensional, dalam rangka membiayai proyek tertentu secara bersama-sama. Sedangkan entitas sindikasi adalah kumpulan beberapa Lembaga Keuangan Syariah, atau Lembaga Keuangan Syariah dengan Lembaga Keuangan Konvensional, yang memberikan pembiayaan secara bersama kepada nasabah.6 Berdasarkan beberapa tinjauan terhadap pengertian pembiayaan sindikasi tersebut, maka dapat disimpulkan bahwa pembiayaan sindikasi syariah adalah jenis pembiayaan yang dilakukan oleh Bank Syariah yang bermitra dengan Bank Syariah lain atau dengan bank konvensional untuk membiayai sebuah proyek strategis perekonomian berdasarkan prinsip syariah.

Pembiayaan sindikasi menjadi salah satu startegi yang dapat dilakukan oleh perbankan syariah untuk mendapat dorongan asset industri perbankan syariah secara relatif aman. Dengan pemberlakuan sindikasi, perbankan syariah dapat masuk ke dalam sektor korporasi maupun proyek infrastruktur pemerintah. Perbankan syariah berpotensi mendapatkan keuntungan yang besar, namun juga dapat memitigasi risiko yang relatif besar.7 Pembiayaan sindikasi ini ditujukan untuk menyalurkan pembiayaan tanpa perlu

${ }^{4}$ Sutan Remy Sjahdeini, Kredit Sindikasi: Proses Pembentukan dan Aspek Hukum, (Jakarta: Midas Surya Grafindo, 1997), hlm. 2.

5 Adiwarman A. Karim, Bank Islam Analisis Fiqih dan Keuangan, (Jakarta : PT Raja Grafindo Persada, 2010), hlm, 245.

6 Fatwa Dewan Syariah Nasional Majelis Ulama Indonesia Nomor: 91/DSN-MUI/IV/2014 tentang Pembiayaan Sindikasi

7 Rahmayati, "Pembiayaan Sindikasi Sebagai Peningkatan Portofolio Pembiayaan Perbankan Syariah," Jurnal Ilmu Ekonomi Dan Keislaman 7, no. 1 (June 24, 2019): 1-16, http://194.31.53.129/index.php/Al-masharif/article/view/1617. 
merasa khawatir terhadap batas maksimum pemberian kredit di lembaga keuangan dan untuk meningkatkan pendapatan lembaga keuangan dengan memperkecil adanya risiko pembiayaan besar yang terjadi, apabila terdapat risiko dikemudian hari maka seluruh anggota sindikasi harus bersedia menanggung secara bersama-sama seluruh risiko yang muncul karena penyaluran pembiayaan tersebut. 8

\section{2) Bentuk-bentuk dan Proses Pembentukan Pembiayaan Sindikasi}

Pembiayaan sindikasi sebelum diproses di bank, terlebih dahulu harus melalui beberapa tahapan. Adapun prosedur dalam pembentukan sindikasi yakni melalui pembentukan arrangers, penunjukan lead manager dan pembentukan managing group penyampaian offer dan penerimaan mandat, penyiapan information memorandum dan perjanjian kredit, penunjukan agent bank, upacara penandatangan perjanjian kredit sindikasi dan setelah perjanjian pembiayaan sindikasi ditandatangani, maka dilakukan publisitas atas terbentuknya sindikasi kepada penerima pembiayaan. ${ }^{9}$

Pembiayaan sindikasi secara teoritis jika ditinjau berdasarkan bentuknya dapat dibagi ke dalam beberapa macam yakni lead syndication, club deal, dan sub syndication. Adapun pembagiannya adalah sebagai berikut: 10

a. Lead syndication adalah kumpulan bank yang secara bersama-sama membiayai suatu proyek dan dipimpin oleh satu bank yang bertindak sebagai leader. Dana yang diberikan oleh setiap bank akan dilebur menjadi satu, sehingga keuntungan/ kerugian menjadi hak dan tanggung-jawab bersama, sesuai dengan proporsi modalnya.

b. Club deal merupakan kumpulan bank yang bersama-sama memiliki tujuan untuk membiayai sebuah proyek, akan tetapi antara bank yang satu dengan bank lainnya tidak mempunyai hubungan kerjasama bisnis (penyatuan modal). Dengan kata lain, setiap bank akan membiayai suatu bidang yang berbeda dalam satu proyek tertentu. Sehingga setiap bank akan memperoleh keuntungan sesuai dengan bidang yang dibiayai dalam proyek tersebut. Hubungan antar entitas sindikasi dalam kategori ini dapat disebut juga sebagai hubungan koordinatif.

c. Sub syndication ialah sindikasi yang terlaksana antara suatu bank dengan salah satu bank peserta sindikasi lain yang kerjasama bisnisnya tidak memiliki berhubungan secara langsung dengan peserta sindikasi lainnya.

\section{B. .Mekanisme Pembiayaan Sindikasi Bank Syariah di Indonesia}

Pembiayaan sindikasi muncul dalam perbankan atas dasar kebutuhan terhadap pembiayaan dengan jumlah besar, sehingga perbankan tidak mampu jika hanya dilakukan oleh satu bank saja. Di lain sisi, pembiayaan jumlah besar juga pasti diikuti dengan resiko yang besar pula. Pembiayaan sindikasi hadir sebagai salah satu cara untuk memperkecil resiko karena pembiayaan dilakukan oleh dua bank atau lebih sehingga akan mencerminkan prinsip berbagi resiko. Perbankan syariah di Indonesia telah banyak

8 Mardiana Yose and Rully Trihantana, "Peran Serta Dan Mekanisme Bank Syariah Pada Pembiayaan Sindikasi Di Bank Syariah Mandiri Pusat," Nisbah: Jurnal Perbnakan Syariah 3, no. 2 (December 18, 2017): hlm, 410, https://doi.org/10.30997/jn.v3i2.814.

${ }^{9}$ Sutan Remy Sjahdeini, Kredit Sindikasi: Proses, ,נ, hlm. 14.

10 Adiwarman A. Karim, Bank Islam Analisis Fiqih dan Keuangan,,,, hlm. 246. 
melakukan pembiayaan terhadap investasi jumlah besar yang sangat berpengaruh kepada perekonomian. Misalnya melalui produk Pembiayaan Sindikasi iB Hasanah di BNI Syariah, Kredit Sindikasi di Bank Syariah Mandiri, Sindikasi di BCA Syariah dan pembiayaan sindikasi perbankan syariah lainnya di Indonesia. Pembiayaan terhadap investasi ini tidak dapat dijalankan sendiri oleh satu Bank Syariah, melainkan harus bekerja sama dengan bank lainnya. Berikut ini merupakan contoh aplikasi pembiayaan sindikasi yang dilakukan oleh beberapa Bank Syariah di Indonesia:

\section{3) Pembiayaan Sindikasi di Bank Syariah Mandiri}

Skema pembiayaan sindikasi di Bank Syariah Mandiri setidaknya membutuhkan waktu enam bulan. Pembiayaan sindikasi di BSM memiliki syarat yakni bukti permohonan dari nasabah, bukti legalitas pemohon, bukti legalitas usaha, laporan keuangan dua tahun terakhir dan laporan keuangan tahun berjalan, serta bukti kepemilikkan agunan, dokumen pendukung lain (jenis kontrak, company profile, dan lain sebagainya). Persyaratan tersebut harus dilengkapi oleh calon nasabah yang ingin memperoleh pembiayaan sindikasi melalui BSM dan ketentuan tersebut dijalankan oleh BSM sebagai standar prudential banking untuk memperkecil risiko kerugian bagi bank.

Apabila persyaratan tersebut telah terpenuhi, maka selanjutnya dapat dilakukan proses selanjutnya. Ada dua tingkatan dalam proses mendapatkan pembiayaan sindikasi yakni primary market syndication dan secondary market syndication. Primary market syndication adalah pasar berlangsungnya proses sindikasi, dimulai dari pembentukkan sampai sebelum akad pembiayaan sindikasi ditandatangani. Sedangkan secondary market syndication adalah pasar yang terbentuk jika salah satu peserta sindikasi menjual sebagian atau seluruh partisipasinya kepada bank lainnya. Adapun skema yang terjadi dalam produk pembiayaan sindikasi di BSM dapat dideskripsikan melalui gambar berikut ini. ${ }^{11}$

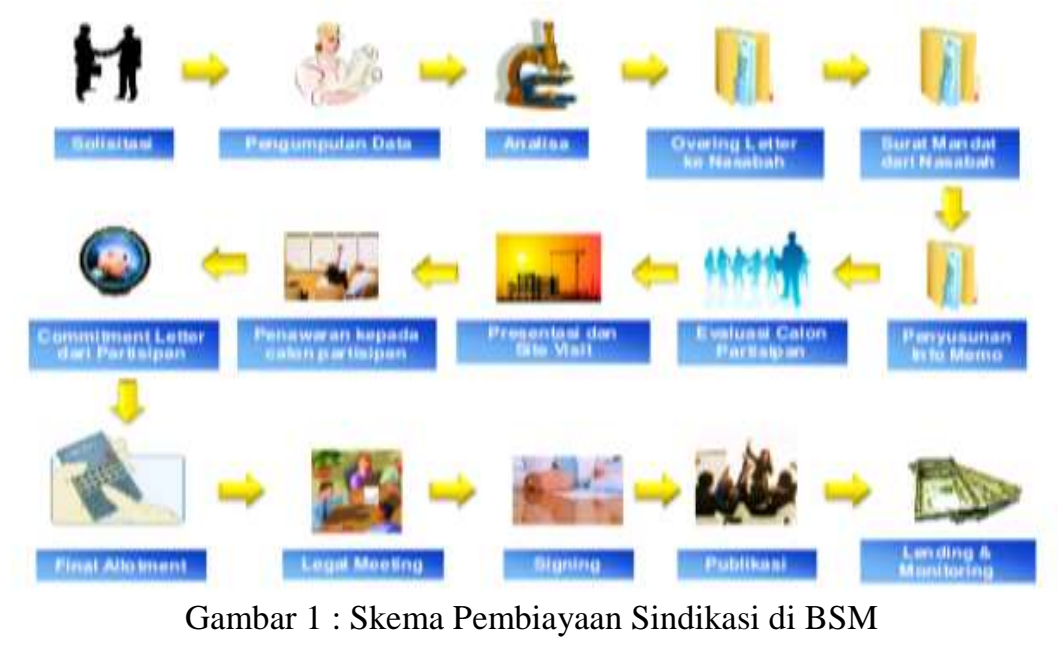

Dalam pembiayaan sindikasi, apabila Bank Syariah Mandiri bertindak sebagai leader maka proses dan alunya dapat dirumuskan melalui tahapan berikut ini: ${ }^{12}$

11 Yose and Trihantana, "Peran Serta Dan Mekanisme Bank Syariah Pada Pembiayaan Sindikasi Di Bank Syariah Mandiri Pusat," hlm. 411.

12 Yose and Trihantana, hlm. 412. 
a. Bank dan nasabah bernegosiasi. Pada negosiasi ini bank akan menawarkan produk sindikasi, jumlah angsuran dan jumlah marginnya. Kemudian dilanjutkan pengumpulan berkas persyaratan. Bank akan menganalisis berkas-berkas persyaratan, apakah nasabah layak diberikan pembiayaan atau tidak.

b. Bank akan mengirimkan offering letter dengan kondisi underwitten basis yaitu dimana Bank melakukan pengikatan diri untuk menyediakan sebagian (partially underwritten) atau seluruh (fully underwritten) dari seluruh jumlah dana pembiayaan.

c. Bank meminta mandat dan penunjukkan sebagai MLA. Kemudian Bank akan menyusun info memo yang berisikan informasi mengenai profil usaha nasabah, dan term \& condition dari pembiayaan sindikasi

d. Bank akan menawarkan pembiayaan proyek tersebut kepada beberapa bank yang mempunyai kemampuan sindikasi dengan mengirimkan surat penawaran disertai info memo. Setelahnya, MLA beserta lembaga keuangan calon anggota sindikasi melakukan analisis terhadap proyek tersebut dan mempresentasikan kepada para komite pembiayaan dari setiap bank.

e. Jika lembaga keuangan tertarik pada usaha nasabah, maka setiap bank akan menyampaikan komitmen mereka ke dalam bentuk participation letter. Sesudah para partisipan bersedia berpartisipasi, Bank bersama peserta sindikasi akan memberikan term sheet final kepada nasabah yang meliputi mencantumkan jumlah limit pembiayaan dan porsi partisipasi dari setiap peserta sindikasi.

f. Legal meeting oleh Bank selaku wakil dari lembaga keuangan peserta sindikasi, konsultan hukum independen atau lawyer, notaris dan nasabah.

g. Jaminan akan dikuasai secara paripasu oleh peserta sindikasi sesuai dengan proporsi jumlah penyertaan modalnya.

h. Sesudah sindikasi terbentuk, maka dilakukan penandatanganan akad yang diikuti dengan pemasangan iklan (public expose) di media terkemuka tentang pembiayaan sindikasi tersebut.

i. BSM sebagai lead akan mencairkan pembiayaan tersebut dn selanjutnya ialah memonitoring kewajaran pembiayaan, monitoring pembayaran, monitoring kewajiban jatuh tempo, monitoring masa berlaku asuransi, monitoring masa berlaku legalitas usaha, monitoring masa berlaku pembiayaan, monitoring pembentukkan Penyisihan Penghapusan Aktiva (PPA) dan monitoring penyampaian laporan nasabah kepada lead arranger. Dan pencairan dengan cara diangsur setiap kali nasabah membutuhkannya.

j. Selama berlangsungnya proyek nasabah, facility agent bertugas dalam pengumpulan margin, yang selanjutnya akan menyerahkan margin tersebut kepada lead sindikasi.

$\mathrm{k}$. Sesudah seluruh proses sindikasi selesai, maka facility agent akan memberikan invoice sebagai pemberitahuan atas tagihan nasabah.

Namun apabila Bank Syariah Mandiri bertugas sebagai anggota sindikasi atau participant maka prosedurnya sedikit berbeda. Dimana diawali dengan BSM menerima surat penawaran sindikasi dari MLA atau lead sindikasi, kemudian menilai kapasitas dan kredibilitas bank yang akan bertindak sebagai lead, selanjutnya senantiasa mempertimbangkan seluruh faktor risk \& return balance, sesudahnya harus menganalisa pembiayaan sindikasi tersebut yang diikuti dengan penerbitan surat persetujuan kepada 
lead sindikasi, dilanjut dengan mengikuti legal meeting yang diselanggarakan oleh MLA sindikasi untuk membahas draft akad beserta kelengkapannya, dan turut serta menandatangani akad pembiayaan sindikasi. ${ }^{13}$

\section{Pembiayaan sindikasi syariah di Bank Jateng Syariah}

Pembiayaan sindikasi syariah adalah pembiayaan yang dilakukan oleh Bank Jateng Syariah yang bekerjasama dengan beberapa bank lainnya untuk membiayai sebuah proyek yang tidak bisa dipenuhi hanya oleh bank jateng syariah berdasarkan limit bank jateng syariah senilai Rp 500.000.0000. Setiap bank ikut bekerjasama memberikan kontribusi sesuai dengan kesepakatan bersama.

Pembiayaan antar bank dilakukan menggunakan akad musyarakah, sedangkan Bank Jateng Syariah menggunakan akad musyarakah mutanaqishah dalam hal menjual objek pembiayaan sindikasi syariah tersebut kepada nasabah. Sehingga aset kepemilikan dari objek pembiayaan tersebut akan berpindah kepemilikan kepada nasabah setiap bulannya. Hal demikian terjadi karena setiap angsuran yang dibayarkan nasabah setiap bulannya akan mengurangi aset bank yang terdapat pada objek sampai aset objek tersebut berpindah kepemilikan secara 100\%. Sedangkan akad musyarakah mutanaqishah sendiri merupakan gabungan dari akad musyarakah dan juga akad ijarah. Akad musyarakah disini terjadi karena pada pembiayaan sindikasi nasabah memberikan kontribusi sebagai uang muka. Dan akad ijarah terjadi karena pada setiap angsuran yang dibayarkan oleh nasabah tersebut juga ditambahkan dengan biaya sewa setiap bulannya. ${ }^{14}$

\section{Contoh pembiayaan sindikasi di BNI syariah}

Sebagai bahan studi kasus terkait pembiayaan sindikasi yang dilakukan oleh perbankan syariah di Indoensia. BNI Syariah pada bulan agustus tahun 2020 kemarin telah menyalurkan pembiayaan sindikasi dalam proyek Sistem Penyediaan Air Minum (SPAM) Kali Angke, Kota Tangerang Selatan, Provinsi Banten senilai Rp. 126 miliar dari total pembiayaan sindikasi Rp226 miliar.

Dalam pembiayaan sindikasi ini, BNI Syariah berperan sebagai Mandated Lead Arranger dan Bookrunner (MLAB), facility agent (agen fasilitas), escrow agent (agen escrow), dan security agent (agen jaminan). Selain BNI Syariah, ada 2 Bank Syariah yang berpartisipasi dalam sindikasi ini yaitu Bank Panin Dubai Syariah dan Bank Jabar Banten Syariah. Sindikasi ini menggunakan akad musyarakah mutanaqisah yang mempunyai jangka waktu pembiayaan maksimum 120 bulan sejak ditandatangani Perjanjian Line Facility pembiayaan musyarakah mutanaqisah. Dalam menyalurkan pembiayaan, BNI Syariah mengutamakan prinsip kehati-hatian dan mitigasi risiko, serta berlandaskan prinsip syariah. Dengan membiayai proyek pemerintah daerah, diharapkan risiko bisnisnya lebih rendah. ${ }^{15}$

13 Yose and Trihantana, hlm. 413.

14 Nurul Dwi Arifiani, "Mekanisme Akad Musyarakah Mutanaqishah (Studi Pada Nasabah Pembiayaan Sindikasi Syariah Di Bank Jateng Syariah)” (UIN Walisongo, 2016).

${ }^{15}$ Ni Putu Eka Wiratmini, BNI Syariah Salurkan Pembiayaan Sindikasi Rp126 Miliar di Proyek Air Minum, Financial Bisnis: https:// finansial.bisnis.com/read/20200820/231/1281342/ bni-syariah- 


\section{Tinjauan Hukum Ekonomi Syariah teradap Pembiayaan Sindikasi Bank Syariah di Indonesia}

Perkembangan bisnis dan keuangan syariah harus ditunjang dengan kepastian hukum atau aturan yang jelas tentang peningkatan fungsi dan peranan dari fiqh muamalah maliyah terhadap kemajuan perekonomian tidak menutup kemungkinan juga dalam hal pembiayaan sindikasi. Hal itulah yang melatar-belakangi beberapa lembaga keuangan syariah untuk mengajukan permohonan fatwa terhadap pembiayaan sindikasi yang sesuai dengan prinsip syariah atau al-tamwil al-mashrifi al-mujamma'. Oleh karena itulah Dewan Syariah Nasional Majelis Ulama Indonesia berkepentingan untuk menetapkan fatwa tentang pembiayaan sindikasi syariah untuk dijadikan sebagai pegangan. Pembiayaan Sindikasi diperbolehkan berdasarkan fatwa DSN-MUI nomor 91 tahun 2014, namun dengan ketentuan-ketentuan yang diatur secara terperinci dalam fatwa tersebut.

Pertama, akad antar sesama peserta sindikasi dapat dilaksanakan berupa akad mudharabah, musyarakah, dan wakalah. Dalam penggunaan akad mudharabah, para peserta sebagai pihak yang menyertakan modal atau shahibul mal dan pihak leader atau yang disebut mudharib hanya menyertakan modal dalam bentuk keahlian/ keterampilan usaha, tidak ikut berpartisifasi dalam penyertaan modal. Akad musyarakah dimaksudkan saat peserta dan leader ikut berpartisifasi dalam pengumpulan modal, dan di antara syarik ditunjuk sebagai leader. Dimana leader berhak memperoleh pendapatan/ penghasilan tambahan dengan akad tersendiri karena kedudukannya sebagai pengelola. Sedangkan penggunaan akad wakalah berarti peserta sebagai muwakkil dan leader berkedudukan sebagai wakil. Dalam hal akad yang dilakukan akad wakalah bil ujrah, maka wakil berhak mendapatkan ujrah.

Senada dengan ketentuan akad yang digunakan dalam pembiayaan sindikasi syariah di atas. Landasan hukum dari pembiayaan syariah di Indonesia dapat diketahui berdasarkan Undang-undang Nomor 21 Tahun 2008 tentang Perbankan Syariah. Di dalamnya menyatakan bahwa yang dimaksud dengan pembiayaan ialah penyediaan dana atau tagihan yang dipersamakan dengan itu berupa transaksi bagi hasil dalam bentuk mudharabah dan musyarakah, akad sewa menyewa dalam bentuk ijarah atau sewa beli dalam bentuk ijarah muntahiyya bit tamlik, transaksi jual beli (murabahah, salam, isthisna'), dan akad pinjam-meminjam dalam bentuk piutang dan qardh. ${ }^{16}$

Kedua, pelaksanaan akad antara entitas Sindikasi dengan nasabah dapat dilangsungkan dengan beberapa akad meliputi akad jual beli (baik jual beli musawamah, murabahah, salam atau salam paralel, istishna' atau istishna' paralel), akad ijarah atau IMBT, musyarakah mutanaqishah, dan akad kerjasama untuk usaha pertanian (muzara'ah, mukhabarah, mugharasah, dan musaqah). Ketiga, penggunaan rekening dan dokumen dalam akad ini memiliki ketentuan bahwa dalam hal sindikasi dilakukan sesama Lembaga Keuangan Syariah, maka rekening, dokumen kontrak serta dokumen-dokumen pendukung lainnya boleh diadministrasikan/ disusun dalam satu dokumen. Sedangkan apabila

salurkan-pembiayaan-sindikasi-rp126-miliar-di-proyek-air-minum, diakses pada tanggal 22 Oktober 2020 Pukul 13:00 WIB.

16 Undang-undang Republik Indonesia Nomor 21 Tahun 2008 tentang Perbankan Syariah 
sindikasi dilakukan antara Lembaga Keuangan Syariah dengan Lembaga Keuangan Konvensional, maka harus menggunakan rekening yang terpisah dan dibuatkan dokumen induk (perjanjian bersama) yang kemudian dibuat dokumen untuk Lembaga Keuangan Syariah tersendiri dan dibuat pula dokumen khusus untuk Lembaga Keuangan Konvensional secara tersendiri. Dan yang terakhir, apabila salah satu pihak tidak menunaikan kewajibannya atau jika terjadi perselisihan di antara para pihak, maka penyelesaiannya dilakukan melalui lembaga penyelesaian sengketa berdasarkan syariah setelah tidak tercapai kesepakatan melalui musyawarah. ${ }^{17}$

Inovasi produk keuangan dan perbankan syariah merupakan tiang pokok dalam upaya pengembangan industri keuangan syariah di Indonesia. Terobosan produk Bank Syariah ditujukan untuk menyediakan sarana kebutuhan transaksi keuangan masyarakat yang selaras dengan kaidah hukum Islam. Inovasi produk secara nyata harus diupayakan agar mampu memodifikasi produk-produk keuangan konvensional menjadi produk yang sesuai dengan prinsip syariah sebagai cara untuk merespon terhadap perkembangan pasar keuangan yang semakin maju dan canggih. ${ }^{18}$ Salah satu inovasi yang cukup berkembang dalam produk pembiayaan di Bank Syariah yakni pembiayaan sindikasi yang menggunakan akad musyarakah mutanaqishah.

Pembiayaan sindikasi di Bank Syariah dalam penerapannya banyak yang menggunakan akad musyarakah, secara spesifik yaitu musyarakah mutanaqishah. Dimana pembiayaan sindikasi syariah harus memenuhi rukun setidaknya terdapat bank-bank yang melakukan kesepakatan untuk memberikan pembiayaan sindikasi kepada suatu nasabah, adanya kesepakatan para bank peserta sindikasi tersebut harus dituangkan dalam suatu akad musyarakah/ sindikasi dan adanya para peserta sindikasi yang melakukan kerja sama dalam suatu objek yaitu pemberian fasilitas pembiayaan syariah kepada nasabah.

Musyarakah mutanaqishah itu sendiri ialah jenis akad kerjasama antara dua pihak atau lebih yang berasal dari lafadz syaraka-yusyriku-syarkan-syarikan-syirkatan yang memiliki arti kerjasama, perusahaan atau kumpulan. Sedangkan mutanaqishah dihasilkan dari lafadz yatanaqishu-tanaqishan-mutanaqishun yang artinya mengurangi secara bertahap. Musyarakah mutanaqishah merupakan akad musyarakah atau syirkah yang kepemilikan barang atau modal salah satu pihak (syarik) berkurang disebabkan pembelian secara bertahap oleh pihak lainnya. ${ }^{19}$ Musyarakah mutanaqishah ialah akad kerjasama bagi hasil yang merupakan penyertaan modal secara terbatas dari satu mitra usaha kepada mitra usaha yang lain untuk jangka waktu tertentu. ${ }^{20}$ Sementara itu pembiayaan musyarakah mutanaqishah adalah produk pembiayaan berdasarkan prinsip syirkatul 'inan, yang porsi (hishshah) modal salah satu syarik (Bank Syariah) berkurang disebabkan

17 Fatwa Dewan Syariah Nasional Majelis Ulama Indonesia Nomor: 91/DSN-MUI/IV/2014 tentang Pembiayaan Sindikasi (al-tamwil al-mashrifi al-mujamma')

18 Ismail Nawawi, Keuangan Islam, (Sidoarjo: Dwi Putra Pustaka Jaya, 2015), hlm. 528.

19 Fatwa Dewan Syariah Nasional Majelis Ulama Indonesia Nomor: 73/DSN-MUI/IX/2008 tentang Musyarakah Mutanaqishah

${ }^{20}$ Ascarya, Akad dan Produk Perbankan Syariah, (Jakarta: Rajawali Press, 2012), hlm. 212 
pengalihan komersial secara bertahap (naqlul hishshah bil 'iwadli mutanaqisah) kepada syarik yang lain (nasabah). ${ }^{21}$

Akad musyarakah mutanaqishah tidak dikenal dalam istilah fiqh klasik layaknya IMBT, akad tersebut lahir seiring perkembangan dan tuntutan dalam lembaga keuangan syariah apakah mampu beradaptasi ataukah tidak. Produk pembiayaan musyarakah mutanaqishah ini digunakan untuk mengimbangi produk KPR untuk pembiayaan perumahan dan properti dari perbankan konvensional. Pemberlakuan modifikasi akad ini dimaksudkan untuk memberikan kemudahan akses pembiayaan bagi umat Islam secara syariah. Akad Pembiayaan musyarakah mutanaqishah merupakan salah satu jenis produk hasil pembaharuan yang dilakukan oleh lembaga keuangan syariah yang dalam hal ini masuk dalam kategori multi akad atau hybrid contract.

Peyebutan hybrid contract istilah bahasa Indonesia disebut dengan multi akad yakni akad yang ganda atau lebih dari satu. ${ }^{22}$ Sedangkan dalam istilah fiqh merupakan terjemahan dari kata Arab yaitu al-'uqud al-murakkabah yang memiliki arti akad ganda/ rangkap. al-'uqud al-murakkabah terdiri dari dua kata al-'uqud dan al-murakkabah. Kata 'aqd secara etimologi artinya meratifikasi, mengokohkan, dan mengadakan perjanjian. Sedangkan secara terminologi 'aqd berarti mengadakan perjanjian atau ikatan yang mengakibatkan munculnya kewajiban. Sedangkan al-murakkabah secara etimologi, yakni mengumpulkan atau menghimpun. ${ }^{23}$ Hybrid contract memiliki arti penggabungan antara dua akad atau lebih menjadi satu nama akad. Secara definitif, hybrid contract adalah kesepakatan nasabah dengan lembaga keuangan untuk melaksanakan transaksi yang terdiri dari lebih dari satu akad.

Berdasarkan uraian kepustakaan dan analisis tentang status pembiayaan sindikasi Bank Syariah di atas, dapat diketahui bahwa pembiayaan sindikasi merupakan pembiayaan yang dilakukan oleh Bank Syariah dalam hal ini bekerjasama dengan bank lainnya untuk melakukan pembiayaan terhadap sebuah proyek/ kebutuhan dari nasabah yang bersifat signifkan (besar). Pembiayaan sindikasi di Bank Syariah rata-rata menggunakan akad musyarakah mutanaqishah, seperti di Bank Syariah Mandiri dan Bank Jateng Syariah. Telah diketahui bahwa akad musyarakah mutanaqishah ialah akad pembiayaan yang diperbolehkan, sebagaimana ketentuan dalam fatwa DSN-MUI nomor 91 tahun 2014 (di samping akad pembiayaan lain yang diperbolehkan seperti musawamah, murabahah, salam atau salam paralel, istishna' atau istishna' paralel), akad ijarah atau IMBT, dan atau akad pembiayaan usaha pertanian). Oleh karena itu, maka pembiayaan sindikasi Bank Syariah di Indonesia telah mengakomodir ketentuan-ketentuan baik dalam Undangundang Perbankan Syariah, KHES, Fatwa DSN, dan peraturan lain yang terkait. Sehingga aplikasi pembiayaan sindikasi syariah pada banyak Bank Syariah di Indonesia pada

21 Fatwa Dewan Syariah Nasional Majelis Ulama Indonesia Nomor: 01/DSN-MUI/X/2013 tentang Pedoman Implementasi Musyarakah Mutanaqisah dalam Produk Pembiayaan

${ }^{22}$ Ali Amin Isfandiar, Analisis Fiqh Muamalah tentang Hybrid Contract Model dan Penerapannya dalam Lembaga Keuangan Syariah, Jurnal Penelitian Vol. 10, No. 2: 2013, hlm. 206.

23 Hasanudin, "Multi Akad Dalam Transaksi Syariah Kontemporer Pada Lembaga Keuangan Syariah di Indonesia”, Multi Akad pada Lembaga Keuangan Syariah, (Mei, 2009), hlm. 3. 
prinsipnya telah selaras dengan Hukum Ekonomi Syariah, namun masih tetap membutuhkan perhatian secara intens dalam hal pengawasannya.

\section{Penutup}

Inovasi produk Bank Syariah dapat dilakukan dengan menerapkan akad yang bersifat hybrid contract atau multi akad. Penerapan al-uqud al-murakkabah atau multi akad pada lembaga keuangan syariah cukup banyak dan beraneka ragam jenisnya, salah satunya yaitu penggunaan akad pembiayaan musyarakah mutanaqishah. Pembiayaan musyarakah mutanaqishah ini dapat dijumpai pada beberapa produk Bank Syariah diantaranya yakni pembiayaan sindikasi syariah. Secara umum, pembiayaan sindikasi Bank Syariah di Indonesia telah mengakomodir ketentuan-ketentuan baik dalam Undang-undang Perbankan Syariah, KHES, Fatwa DSN, dan peraturan lain yang terkait. Sehingga penerapan pembiayaan sindikasi syariah pada Bank Syariah di Indonesia pada prinsipnya telah selaras dengan Hukum Ekonomi Syariah.

Akad musyarakah mutanaqishah merupakan penggabungan dari akad musyarakah dan juga akad ijarah. Dalam konteks pembiayaan sindikasi, akad musyarakah disini terjadi karena pada pembiayaan sindikasi nasabah memberikan kontribusi sebagai uang muka. Sementara akad ijarah terjadi karena pada setiap angsuran yang dibayarkan oleh nasabah tersebut juga ditambahkan dengan biaya sewa setiap bulannya. Sehingga aset kepemilikan dari objek pembiayaan tersebut akan berpindah kepemilikan kepada nasabah setiap bulannya. Hal demikian terjadi karena setiap angsuran yang dibayarkan nasabah setiap bulannya akan mengurangi aset bank yang terdapat pada objek sampai aset objek tersebut berpindah kepemilikan secara utuh.

\section{Daftar Pustaka}

Arifiani, Nurul Dwi. "Mekanisme Akad Musyarakah Mutanaqishah (Studi Pada Nasabah Pembiayaan Sindikasi Syariah Di Bank Jateng Syariah).” UIN Walisongo, 2016.

Ascarya. Akad dan Produk Perbankan Syariah. Jakarta: Rajawali Press, 2012.

Ascarya dan Diana Yumanita. Gambaran Umum Bank Syariah. Jakarta: PPSK BI, 2005.

Fatwa Dewan Syariah Nasional Majelis Ulama Indonesia Nomor: 73/DSN-MUI/IX/2008 tentang Musyarakah Mutanaqishah

Fatwa Dewan Syariah Nasional Majelis Ulama Indonesia Nomor: 91/DSN-MUI/IV/2014 tentang Pembiayaan Sindikasi (al-tamwil al-mashrifi al-mujamma')

Hasanudin. "Multi Akad dalam Transaksi Syariah Kontemporer pada Lembaga Keuangan Syariah di Indonesia”. Ciputat: UIN Syarif Hidayatullah. Mei, 2009.

Isfandiar, Ali Amin. Analisis Fiqh Muamalah tentang Hybrid Contract Model dan Penerapannya dalam Lembaga Keuangan Syariah, Jurnal Penelitian Vol. 10, No. 2: 2013.

Karim, Adiwarman A. Bank Islam Analisis Fiqih dan Keuangan. Jakarta : PT Raja Grafindo Persada, 2010.

Keputusan Dewan Syariah Nasional Majelis Ulama Indonesia Nomor: 01/DSN-MUI/X/2013 tentang Pedoman Implementasi Musyarakah Mutanaqisah dalam Produk Pembiayaan

Nawawi, Ismail. Keuangan Islam. Sidoarjo: Dwi Putra Pustaka Jaya, 2015.

Rahmayati. "Pembiayaan Sindikasi Sebagai Peningkatan Portofolio Pembiayaan Perbankan Syariah." Jurnal Ilmu Ekonomi Dan Keislaman 7, no. 1 (June 24, 2019): 1-16. http://194.31.53.129/index.php/Al-masharif/article/view/1617. 
Sjahdeini, Sutan Remy. Kredit Sindikasi: Proses Pembentukan dan Aspek Hukum. Jakarta: Midas Surya Grafindo, 1997.

Undang-undang Republik Indonesia Nomor 21 Tahun 2008 tentang Perbankan Syariah

Wiratmini, Ni Putu Eka. Sindikasi Syariah Berpotensi Naik. Financial Bisnis, https://finansial.bisnis.com/read/20200209/90/1199080/sindikasi-syariah-berpotensinaik, diakses pada tanggal 18 Oktober 2020 Pukul 13:00 WIB

Wiratmini, Ni Putu Eka. BNI Syariah Salurkan Pembiayaan Sindikasi Rp126 Miliar di Proyek Air Minum, Financial Bisnis: https:// finansial.bisnis.com/read/20200820/231/1281342/bni-syariah-salurkan-pembiayaansindikasi-rp126-miliar-di-proyek-air-minum, diakses pada tanggal 22 Oktober 2020 Pukul 13:00 WIB

Yose, Mardiana, and Rully Trihantana. "Peran Serta dan Mekanisme Bank Syariah Pada Pembiayaan Sindikasi Di Bank Syariah Mandiri Pusat." Nisbah: Jurnal Perbnakan Syariah 3, no. 2 (December 18, 2017): 403. https://doi.org/10.30997/jn.v3i2.814.

Yozika, Ferlangga Al, and Nurul Khalifah. "Pengembangan Inovasi Produk Keuangan Dan Perbankan Syariah Dalam Mempertahankan Dan Meningkatkan Kepuasan Nasabah." Jurnal Ilmiah Edunomika 1, no. 02 (August 21, 2017). https://doi.org/10.29040/jie.v1i02.154. 